\title{
Electrophoretic Deposition of Titanium Dioxide Thin Films for Photocatalytic Water Purification Systems
}

\author{
Francis Nyongesa*, Bernard Aduda \\ Department of Physics, University of Nairobi, Nairobi, Kenya
}

Email address:

fnyongesa@uonbi.ac.ke (F. Nyongesa)

${ }^{*}$ Corresponding author

\section{To cite this article:}

Francis Nyongesa, Bernard Aduda. Electrophoretic Deposition of Titanium Dioxide Thin Films for Photocatalytic Water Purification Systems. Advances in Materials. Vol. 6, No. 4, 2017, pp. 31-37. doi: 10.11648/j.am.20170604.11

Received: July 19, 2017; Accepted: July 28, 2017; Published: August 22, 2017

\begin{abstract}
In this study, electrophoretic deposition (EPD) technique was used to deposit titanium dioxide $\left(\mathrm{TiO}_{2}\right)$ thin films on conducting glass substrates for application in water purification from organic contaminants. Phenol was used as a model pollutant. The EPD suspension related parameters and deposition conditions were first optimized for good quality film deposits. The suspension stability and deposition conditions that result in good adherence of $\mathrm{TiO}_{2}$ particles to the substrate with homogeneous film coatings, is ethanol with a $\mathrm{pH}$ of 3.0 , a $\mathrm{TiO}_{2}$ solid loading of $4.0 \mathrm{wt} \%$, a $0.2 \mathrm{wt} \%$ iodine concentration in the solvent and a deposition voltage of $20.0 \mathrm{~V}$ in a time of $210.0 \mathrm{~s}$. The photocatalytic activity of $\mathrm{TiO}_{2}$ thin films decreases exponentially with the ultraviolet light (UV) illumination time and it is also dependent on film thickness, sintering temperature and the intensity of the UV light. Highest rate of photocatalytic activity is observed at an optimal film thickness of $95.0 \pm$ $2.0 \mu \mathrm{m}$ sintered at $300.0^{\circ} \mathrm{C}$. The implications of these results are discussed for design of inexpensive waste water purification systems for light industries before discharge into the ecosystem.
\end{abstract}

Keywords: Electrophoretic Deposition, Titanium Dioxide, Photocatalysis

\section{Introduction}

In recent years, industrial and agricultural activities have caused significant increase of organic contaminants such as phenol in natural waterways, presenting a toxicological hazard to plants, marine and animal lives. Phenol and its derivatives change the enzyme activity and cell metabolism and are very harmful ecotoxins even at low concentrations [1]. There is therefore need to improve water treatment for human consumption and for proper functioning of the ecosystem. Water treatment using heterogeneous photocatalysis of titanium dioxide $\left(\mathrm{TiO}_{2}\right)$ nanoparticles is one of the advanced water purification systems and it offers great advantages for detoxification of wastewater since it is inexpensive, non-toxic and chemically stable. Titanium dioxide, particularly in the anatase form, exhibits higher photocatalytic activity under ultraviolet (UV) irradiation and has a strong oxidizing power, to decompose organic contaminants into environmentally harmless compounds such as water and carbon dioxide [2-4]. Additionally, complete inactivation of microorganisms such as bacteria, viruses and protozoa can also be achieved [5]. This method also eliminates the foul odor and improves water turbidity [6].

Notably, $\mathrm{TiO}_{2}$ photocatalyst is mostly used to decompose organic contaminants by directly putting it into water ponds, which makes it impossible to be reused again or requires an extra process of filtration of the catalyst. There is therefore a need to develop ways in which this photocatalyst can be used more effectively. One approach is to grow $\mathrm{TiO}_{2}$ on a substrate and to pass liquid stream of contaminated water over them. However, since the reaction velocity of this photocatalyst is slow, it is important to obtain the most suitable thin film that will exhibit the highest photocatalytic activity that can allow the application of water purification in large scale and at low cost.

One of the most effective methods for fabrication of ceramic coatings and films from powder suspensions is Electrophoretic Deposition (EPD) [7]. The EPD technique of materials is a simple, fairly rapid, and cost effective two-step process for thin film preparation. It involves movement of charged particles in a suspension medium followed by 
deposition of the particles on a substrate under an applied DC voltage [7-14]. With EPD, it is possible to prepare homogeneous coated layers and the thickness of deposited films may be controlled by varying the EPD deposition parameters such as the choice of solvent (suspension), the zeta potential (through the charging mechanism), solid loading of the particles in the suspension and the deposition conditions such as the DC voltage and deposition time [1517]. Different combinations of EPD deposition parameters have been applied by various authors to deposit $\mathrm{TiO}_{2}$ thin films for applications in DSCs [18-28], in ceramic coatings [29-32] and biomedical applications [33-35].

In the present study, the effect of EPD deposition parameters (type of solvent and $\mathrm{pH}$ of suspension, concentration of $\mathrm{TiO}_{2}$ in the solvent, deposition time and the applied voltage) on the quality of films deposited by EPD has been investigated to determine the optimal parameters for a homogeneous, good-quality $\mathrm{TiO}_{2}$ deposits. Photocatalytic activity of $\mathrm{TiO}_{2}$ nanoparticles deposited at optimal parameters was then explored for decomposition of organic contaminants in waste water using phenol as a model pollutant.

\section{Materials and Methods}

\subsection{Optimization of EPD Suspension Related Parameters}

Glass substrates coated with a conducting layer of fluorine doped tin oxide (FTO) were used as the electrodes in EPD cell. The FTO glass substrates were cleaned using detergent solution in a sonicator for $20.0 \mathrm{~min}$. and rinsed using distilled water. They were then sonicated in ethanol for $20.0 \mathrm{~min}$. after which they were again rinsed using distilled water in ultrasonic bath. The EPD apparatus consisted of a cell (Pyrex glass beaker) and a DC power supply (Thurlby Thadar TS30225). The electrodes were partially immersed in suspension containing $\mathrm{TiO}_{2}$ nanopowder (CAS No. 1346367-7, Aldrich) dispersed in a solvent as shown in Figure 1.

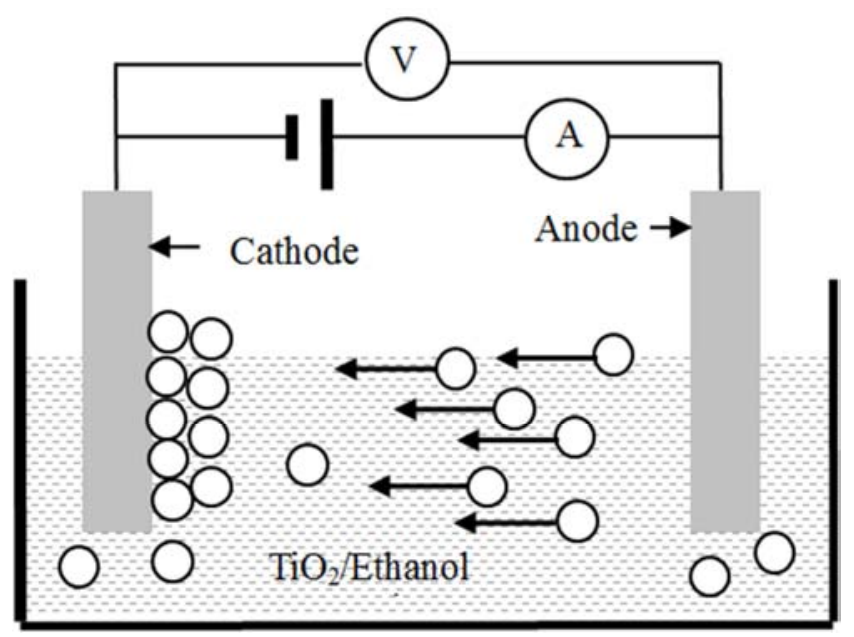

Figure 1. Schematic set-up of the EPD cell.

The cross section part of the substrate (cathode) and the counter electrode (anode) that was under the suspension was $1.5 \times 1.5 \mathrm{~cm}^{2}$ and they were placed $1.5 \mathrm{~cm}$ apart. The EPD suspension related parameters were optimized by studying the effect of different solvents, the $\mathrm{pH}$ and the solid loading of $\mathrm{TiO}_{2}$ in the suspension respectively at a deposition voltage of $20.0 \mathrm{~V}$ for $2.0 \mathrm{~min}$. After deposition, the film quality were inspection to determine the optimal deposition conditions in terms of surface quality i.e., adherence of $\mathrm{TiO}_{2}$ particles to the substrate, film homogeneity and uniformity.

Different solvents were tested including distilled water, ethanol, 2-propanol (IPA: Isopropyl alcohol) and toluene respectively. The solvents were prepared in glass beakers containing the same solid loading of $3.0 \mathrm{wt} \%$ of $\mathrm{TiO}_{2}$ nanoparticles. The effect of $\mathrm{pH}$ was analyzed using six suspensions with $\mathrm{pH}$ values in the range 1 to 6 , obtained by addition of nitric acid to the solvent while keeping the other parameters constant (i.e., $3.0 \mathrm{wt} \% \mathrm{TiO}_{2}$ solid loading and same solvent as predetermined in previously experiments). The effect of solid loading was investigated by using different $\mathrm{TiO}_{2}$ solid loadings ranging from 0.1 to $10.0 \mathrm{wt} \%$ of $\mathrm{TiO}_{2}$.

The zeta potential is an important parameter which determines the suspensions stability and the particle mobility, and is dependent on the $\mathrm{pH}$ of the suspension [8]. A high zeta potential improves the stability of the suspension. In this study, the charging mechanism was varied by addition of different amounts of iodine ranging from 0.01 to $0.80 \mathrm{wt} \%$ to the EPD suspension. The amount of iodine is reported as wt $\%$ with respect to $\mathrm{TiO}_{2}$ solid loading in the suspension. For comparison, $\mathrm{TiO}_{2}$ suspension without any iodine was used as a reference suspension.

\subsection{Optimization of Process-Related Parameters}

By using the predetermined optimized EPD suspension related parameters from previous experiments, EPD was carried out at constant deposition time of $2.0 \mathrm{~min}$. using different applied voltages of 10.0, 15.0, 20.0, 25.0 and $30.0 \mathrm{~V}$ respectively. Thereafter, EPD was carried out at a constant applied voltage of $20.0 \mathrm{~V}$ and for varying deposition times ranging from 1.0 to $5.0 \mathrm{~min}$. After deposition, the $\mathrm{TiO}_{2}$ coated substrates were carefully extracted from the suspension and the weight of the deposit was determined by weighing the electrodes before and after deposition using a $10^{-4} \mathrm{~g}$ precision balance (E. Mettler, Zurrich). Some $\mathrm{TiO}_{2}$ coated substrates were thermally treated in an electric furnace (Nobertherm $\mathrm{LH} 15 / 14$ ) at $300.0^{\circ} \mathrm{C}, 400.0^{\circ} \mathrm{C}$ and $700.0^{\circ} \mathrm{C}$ respectively for 3.0 hours at a heating rate of $5.0^{\circ} \mathrm{C} / \mathrm{min}$ to achieve good adhesion.

\subsection{Characterization of $\mathrm{TiO}_{2}$ Thin Films}

The thickness of the films was measured using ALPHA STEP Q equipment. The samples were mounted on the holder and adjusted so that the profiler was directly above the surface to be scanned. The scan length, which was set approximately at $2.0 \mathrm{~cm}$, was such that it included coated and uncoated surfaces. The uncoated surface was obtained by 
taping part of the substrate that was to be placed in the EPD cell such that the $\mathrm{TiO}_{2}$ particles were coated on the tape instead of the substrate. By removing the tape, a step was created. The profiler measured the difference in height at the junction between the coated and uncoated surfaces. The surface morphology of the films was investigated using a scanning electron microscope (SEM) in a JEOL 5400 microscope. Structural analysis was conducted using Shimadzu X-Ray Diffractometer with $\mathrm{Cu} \mathrm{K} \alpha$ radiation with a scanning range of $2 \theta$ from $10^{\circ}-60^{\circ}$.

\subsection{Photocatalytic Activity of $\mathrm{TiO}_{2}$}

Different concentrations of phenols were made ranging from 5.0 parts per million (ppm) to $100.0 \mathrm{ppm}$ by adding phenol crystals to distilled water in a beaker at room temperature. These are the typical concentrations from many industries although the concentration may go as high as 500.0 ppm. Photocatalytic activity of $\mathrm{TiO}_{2}$ coatings were evaluated in a laboratory set-up where $\mathrm{TiO}_{2}$ coated glass substrates at optimized parameters, were immersed in $50.0 \mathrm{ml}$ phenol solution in a beaker and illuminated by UV lamps (CIGIEMME, ITALY) whose dominant emission was centered at $365.0 \mathrm{~nm}$. For comparison, illumination on similar coated substrates was also done using direct sunlight. The photocatalytic activity of the titania coatings was evaluated based on the decomposition rate of phenol using the Bromination method [36]. The intensity of the UV light was measured using a digital radiometer (SPECTROLINE DSE-100).

\section{Results and Discussions}

\subsection{Effect of EPD Deposition Parameters on Film Quality}

Ethanol was found to be a better solvent compared to toluene, propanol or water. This was due to its high dielectric constant, $(\varepsilon=24.3)$. Although water has a higher dielectric constant, it caused electrolysis even at low voltages resulting in gas evolution on the electrodes. Suspension conditions that gave good adherence of $\mathrm{TiO}_{2}$ particles to the substrate with homogeneous coatings were a $\mathrm{pH}$ value of 3.0, a solid loading of $4.0 \mathrm{wt} \%$ and $0.2 \mathrm{wt} \%$ iodine concentrations in the solvent. For a low $\mathrm{pH}<3.0$ and a high $\mathrm{pH}>5.0$, formation of agglomerates occurred which reduced the deposit mass. This was attributed to a lower zeta potential. Notably, electrophoretic mobility of the particles was highest at a $\mathrm{pH}$ of 3.0 such that more particles reached the substrate within a short period of time indicating a high zeta potential. This is an indication that the zeta potential increased with increase in the iodine concentration, reaching a maximum and thereafter it decreased with further increase in the iodine concentration probably because most of the available sites for ion adsorption were saturated. A low iodine concentration less than $0.2 \mathrm{wt} \%$ was not enough to charge the particles and agglomeration occurred. On the other hand, higher iodine concentrations $>0.3 \mathrm{wt} \%$ resulted in undisolved iodine in the solvent with most of the iodine settling at the bottom of the
EPD cell with $\mathrm{TiO}_{2}$ particles attached to them. Lastly, a high solid loading $>4.0 \mathrm{wt} \%$ caused formation of $\mathrm{TiO}_{2}$ clusters due to high concentration of particles in the solvent resulting in non uniform deposit.

Figure 2 shows the variation of the deposit mass with deposition time for various applied DC voltages at the optimal EPD suspension parameters. It is observed that for constant applied DC voltage, the film deposition mass increased, first nearly linearly (indicating a constant deposition rate) followed by a plateau at high deposition times greater than $210.0 \mathrm{~s}$. This was attributed to diminishing amount of $\mathrm{TiO}_{2}$ particles in the suspension such that fewer particles were available for deposition after long deposition times. Deposition mass remained constant after $210.0 \mathrm{~s}$ for voltages of $20.0,25.0$ and $30.0 \mathrm{~V}$ respectively, indicating saturation.

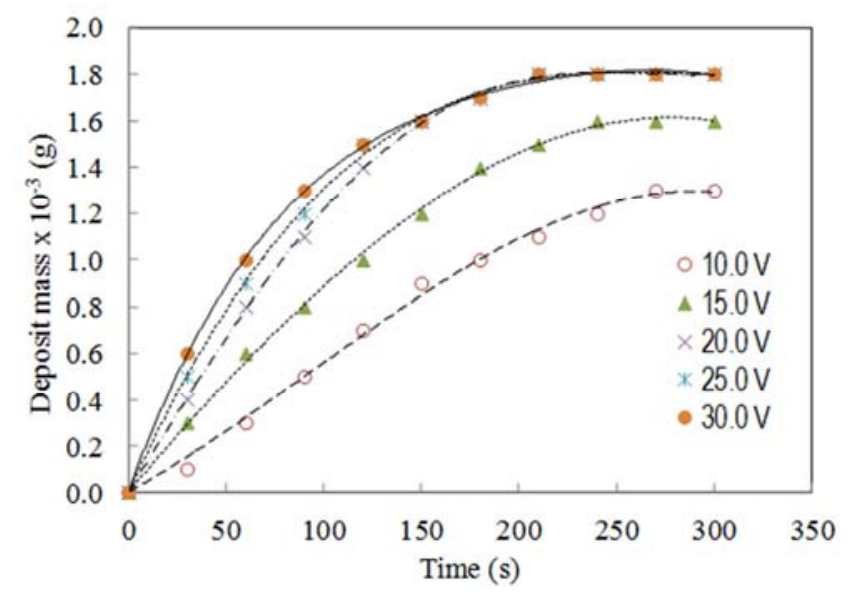

Figure 2. Variation of deposition mass with time for different deposition voltages and a solid loading of $4.0 \mathrm{wt} \%$.

Notably, higher voltages $(>20.0 \mathrm{~V})$ cause high currents resulting in rapid deposit formation with growth of $\mathrm{TiO}_{2}$ clusters as shown in the SEM micrograph of Figure 3(a). At the same time, an increase in hydrolysis of the solvent occurred thereby interfering with particle deposition due to undesirable formation and entrapment of bubbles within the deposit. These effects increased the resistance of the film causing a reduction in the current with a subsequent reduction in electrophoretic mobility such that fewer particles reached the substrate. Similar observations have been made Moreno and Ferarri [14] in aqueous slurries. For applied voltages of 20.0 and $25.0 \mathrm{~V}, \mathrm{TiO}_{2}$ particles adhered well to the substrate and the coating was homogeneous as shown in Fig. 3b. Consequently, $20.0 \mathrm{~V}$ was chosen as the optimal voltage for coating of $\mathrm{TiO}_{2}$ with a deposition time of $210.0 \mathrm{~s}$.

\subsection{Photocatalytic Activity of $\mathrm{TiO}_{2}$}

The photocatalytic activity of $\mathrm{TiO}_{2}$ was found to be dependent on film thickness and sintering temperature among other factors such as the intensity of the UV light. Figure 4 shows the variation in the decomposition rate of phenol with UV illumination, using $\mathrm{TiO}_{2}$ films of varying thicknesses and sintered at $300.0^{\circ} \mathrm{C}$. It is observed that the decomposition rate 
decreased nearly exponentially with increase in illumination time irrespective of the film thickness. On the other hand, for a given illumination time, photocatalytic activity increased with increase in film thickness up to an optimal film thickness of $95.0 \pm 2.0 \mu \mathrm{m}$, beyond which, the effect decreased with further increase in film thickness. This is an indication that very large $\mathrm{TiO}_{2}$ film thickness has the effect of reducing the light penetration depth into the film through absorption and scattering such that less light reaches the $\mathrm{TiO}_{2}$ particles at the bottom of the film. Consequently, this causes a reduction in the number of electron-hole pairs produced, resulting in less photocatalytic effect. A similar observation was made by Chen and Ray [37], for a slurry reactor. Complete oxidation of phenol was observed after 10.0 hours using a film thickness of $95.0 \pm 2.0 \mu \mathrm{m}$.
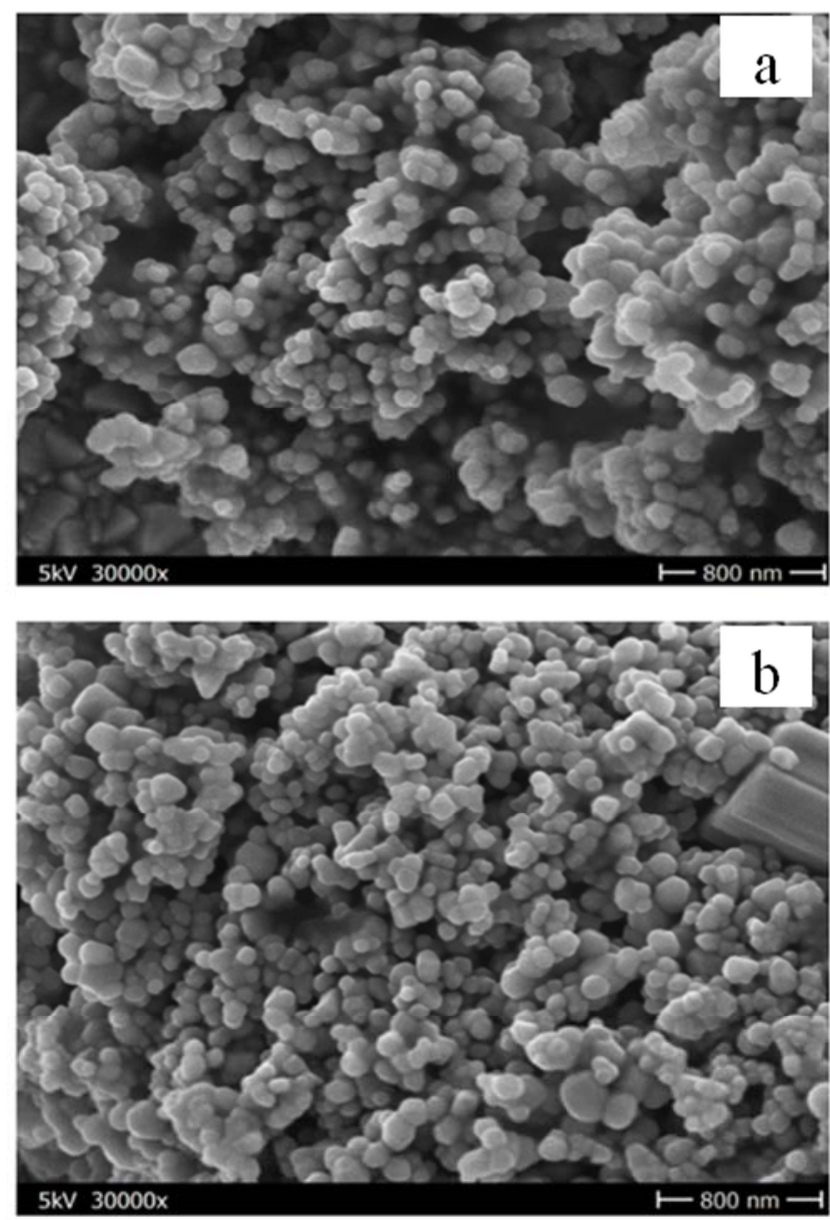

Figure 3. $\mathrm{SEM}$ of $\mathrm{TiO}_{2}$ films deposited at (a) $30.0 \mathrm{~V}$ for 210.0s showing $\mathrm{TiO}_{2}$ clusters and (b) $20.0 \mathrm{~V}$ and 210.0s showing uniform film coating.

Figure 5 shows the effect of sintering temperature of $\mathrm{TiO}_{2}$ films on photocatalytic activity of phenol using film thickness of $33.0 \pm 2.0 \mu \mathrm{m}$. It is observed that photocatalytic activity decreased with increase in the sintering temperature of $\mathrm{TiO}_{2}$ films. This could be attributed to the change in phase when $\mathrm{TiO}_{2}$ is heated in the temperature range $600.0-$ $800.0^{\circ} \mathrm{C}$, where an irreversible conversion of the anatase to rutile phase occurs $[5,38]$. Since anatase is more efficient in photocatalytic activity than rutile, this conversion causes a reduction in photocatalytic activity for films heated above $600.0^{\circ} \mathrm{C}$. This phenomenon is evidenced by the XRD results of Figure 6 which shows an increase in the peak intensities of rutile when heated at $700.0^{\circ} \mathrm{C}$.

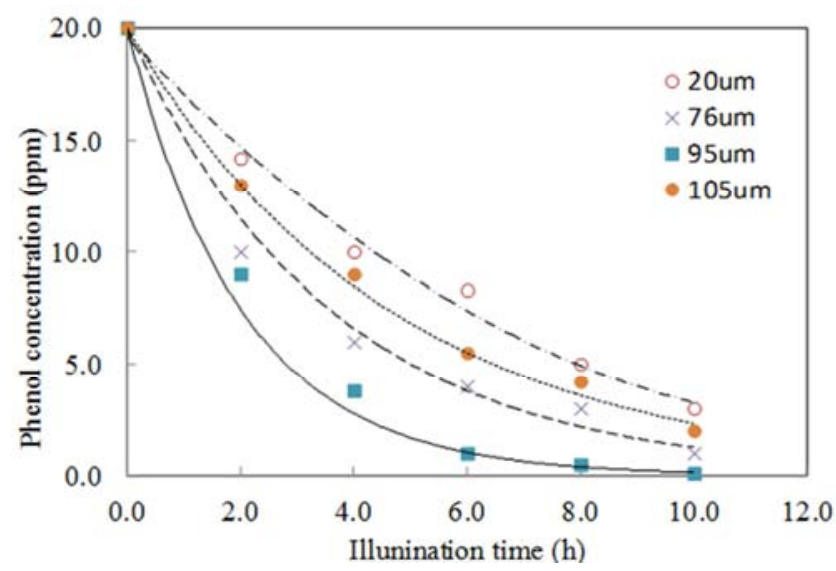

Figure 4. Variation of phenol concentration with illumination time on $\mathrm{TiO}_{2}$ films of varying thicknesses heated at $300.0^{\circ} \mathrm{C}$.

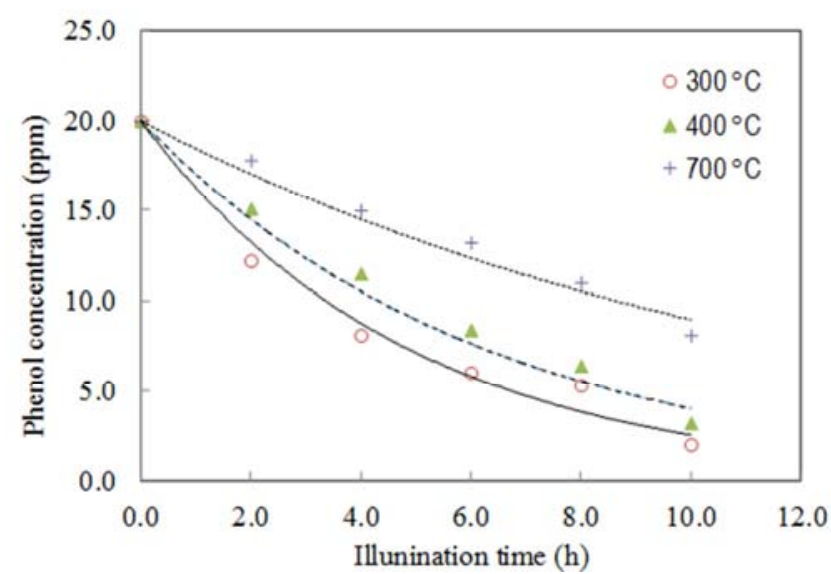

Figure 5. Variation of Phenol concentration with illumination time on $\mathrm{TiO}_{2}$ films sintered at different temperatures.

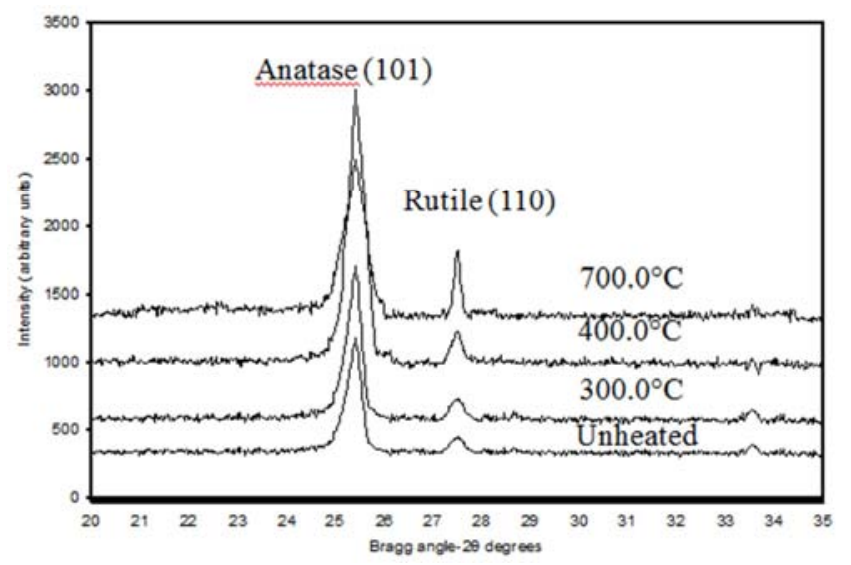

Figure 6. XRD patterns of unheated and heated samples of titanium dioxide showing increase in rutile phase at $700.0^{\circ} \mathrm{C}$.

From Figure 6, the XRD pattern of the unheated $\mathrm{TiO}_{2}$ powder shows the peaks of anatase and rutile at $2 \theta=25.42^{\circ}$ and $27.50^{\circ}$ respectively. The composition of the respective 
phases such as rutile in the original powder of $\mathrm{TiO}_{2}$ was calculated using (1) [5]:

$$
x=\left(1+0.8 \frac{I_{A}}{I_{R}}\right)^{-1}
$$

where $x$ is the weight fraction of rutile in the powder, while $I_{\mathrm{A}}$ and $I_{R}$ are the x-ray peak intensities of anatase and rutile respectively. The results indicated that there was $23.84 \%$ rutile in the unheated samples. Heating at $300.0^{\circ} \mathrm{C}$ and $400.0^{\circ} \mathrm{C}$ for 3 hours resulted in virtually no change in phases of $\mathrm{TiO}_{2}$. However, at $700.0^{\circ} \mathrm{C}$, an increase in the rutile content from from $24.59 \%$ to $45.21 \%$ occurred indicating that rapid transition of anatase to rutile occurs at high temperatures. Similar observation has been made by Allan [32], who noted that high temperatures above $600.0^{\circ} \mathrm{C}$ favour the conversion of antese into rutile. This explains the decrease in the decomposition of rate phenol for films heated at high temperatures.
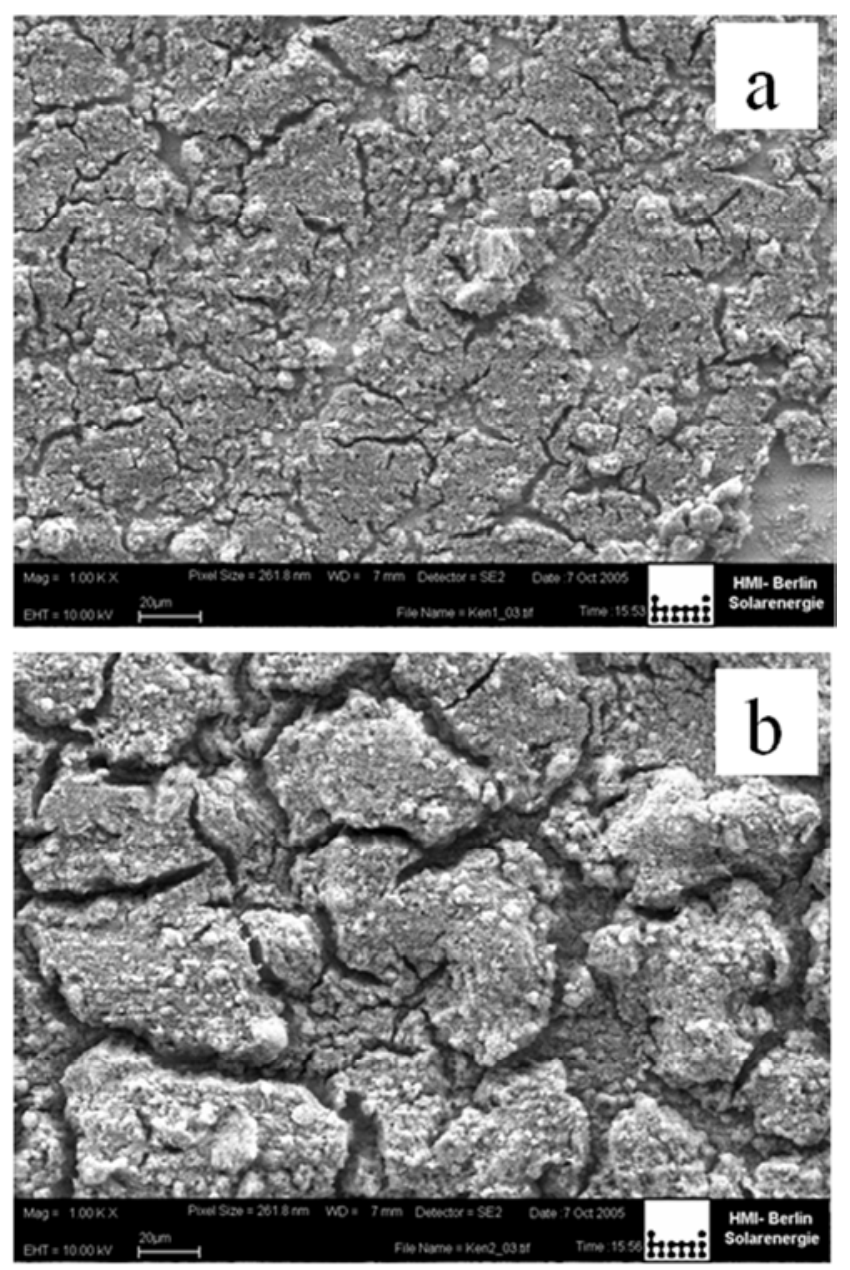

Figure 7. $\mathrm{SEM}$ of $\mathrm{TiO}_{2}$ thin films heated at (a) $400.0^{\circ} \mathrm{C}$ showing few micro cracks, and (b) at $700.0^{\circ} \mathrm{C}$ showing severe micro cracks due to the differential thermal expansion coefficients between anatese and rutile phases.

An important feature to point out is that these phase changes are also accompanied by a reduction in the surface area of the $\mathrm{TiO}_{2}$ particles due to the micro-cracking associated with the mismatch in the thermal expansion coefficients between anatese and rutile. Rutile has a higher thermal expansion coefficient $\left(\alpha_{\mathrm{R}}=6.99 \times 10^{-6} \mathrm{~K}^{-1}\right)$ compared to anatase $\left(\alpha_{\mathrm{A}}=4.47 \times 10^{-6} \mathrm{~K}^{-1}\right)$. As such, during cooling, the differential contraction between these phases causes micro cracking in the $\mathrm{TiO}_{2}$ matrix resulting in reduction in the surface area of the $\mathrm{TiO}_{2}$ particles. Consequently, there are fewer sites for adsorption of the contaminant particles leading to reduced photocatalytic activity. This phenomenon is shown in Figure 7 where it is observed that high sintering temperature $\left(700.0^{\circ} \mathrm{C}\right)$ causes more micro cracking in the matrix compared to samples heated at lower temperatures $\left(400.0^{\circ} \mathrm{C}\right)$.

\subsection{Effect of UV Intensity and Temperature of Phenol on Photocatalytic Activity}

Table 1. shows the effect of UV light intensity on the photocatalytic activity of phenol. It was observed that doubling the UV intensity increased the photocatalytic effect although not by the same proportions. This implies that the rate of photoexitations of the $\mathrm{TiO}_{2}$ particles to form $\mathrm{OH}$ radicals responsible for photocatalytic oxidation is also dependent on other process related factors apart from the amount of UV intensity alone. Also shown in the table is the data for natural sunlight which shows very little photocatalytic effect since sunlight contains only about 4-5\% of UV light (although this may vary from place to place). As such, there is little photo excitation of $\mathrm{TiO}_{2}$ particles to form $\mathrm{OH}$ radicals responsible for photocatalytic oxidation under natural sunlight.

Table 1. Variation in the concentration of phenol (ppm) after illumination with UV light of different intensities for various time durations.

\begin{tabular}{lllll}
\hline \multicolumn{5}{l}{ Illumination intensity } \\
\hline Time (h) & Sunlight & $\mathbf{1 . 8} \mathbf{~} W / \mathbf{c m}^{\mathbf{2}}$ & $\mathbf{3 . 6} \mathbf{~} \mathbf{W} / \mathbf{c m}^{\mathbf{2}}$ & $\mathbf{5 . 4} \mathbf{~} \mathbf{W W} / \mathbf{c m}^{\mathbf{2}}$ \\
\hline 0.0 & $20.0 \pm 0.1$ & $20.0 \pm 0.1$ & $20.0 \pm 0.1$ & $20.0 \pm 0.1$ \\
2.0 & $20.0 \pm 0.1$ & $17.0 \pm 0.1$ & $16.0 \pm 0.1$ & $14.0 \pm 0.1$ \\
4.0 & $20.0 \pm 0.1$ & $14.0 \pm 0.1$ & $12.0 \pm 0.1$ & $9.0 \pm 0.1$ \\
6.0 & $20.0 \pm 0.1$ & $10.0 \pm 0.1$ & $9.0 \pm 0.1$ & $6.0 \pm 0.1$ \\
8.0 & $19.0 \pm 0.1$ & $8.0 \pm 0.1$ & $7.0 \pm 0.1$ & $3.0 \pm 0.1$ \\
10.0 & $19.0 \pm 0.1$ & $4.0 \pm 0.1$ & $3.0 \pm 0.1$ & $1.0 \pm 0.1$ \\
\hline
\end{tabular}

Figure 8 shows how the photocatalytic activity of phenol was affected by the initial temperature of the contaminant. It is observed that the rate of decomposition of phenol increased with increase in the initial temperature of phenol solution. This could be attributed to increased solubility of oxygen in the solution at elevated temperatures. Notably, oxygen acts as an electron scavenger hence trapping holes to avoid recombination with electrons. This ensures that more of the electrons are available to form $\mathrm{OH}$ radicals used for the decomposition of phenol. The overall mineralization process for an organic compound in the presence of oxygen can be summarized by (2) [5].

$$
\mathrm{OH}^{\bullet}+\mathrm{O}_{2}+\mathrm{C}_{n} \mathrm{O}_{m}\left(\mathrm{H}_{(2 n-2 m+2)}\right) \rightarrow n \mathrm{CO}_{2}+(n-m+1) \mathrm{H}_{2} \mathrm{O}+\mathrm{X}
$$


In the above equation, $\mathrm{X}$ represents other mineral salts, which are dependent on the initial composition of the organic compound.

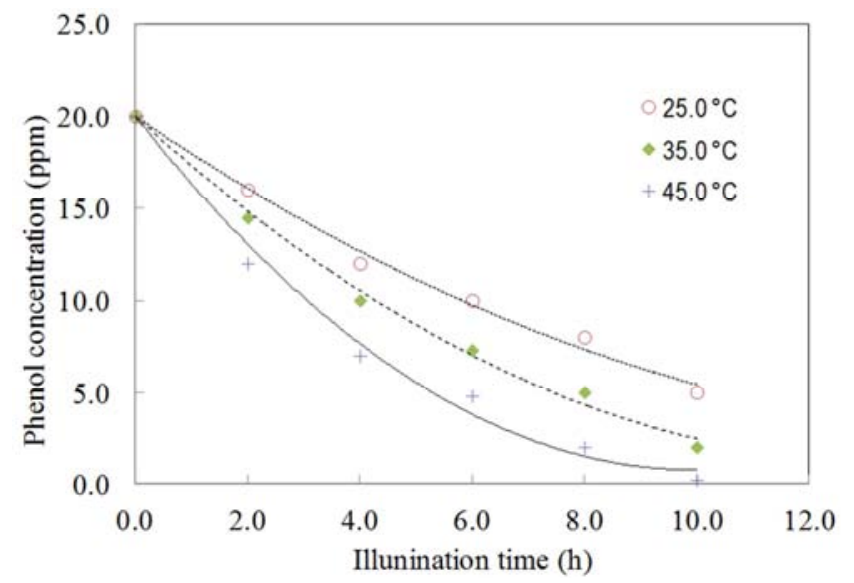

Figure 8. Decomposition of phenol for different initial solute temperature at different time durations.

\section{Discussions}

The implications of the current work are quite significant. First, this study demonstrated EPD as an inexpensive method for thin film coating. However, it is necessary to optimize the suspension and deposition conditions for good quality film deposits. The zeta potential is the most important parameter to monitor since it determines the suspension stability. In is necessary to select the appropriate solvent, $\mathrm{pH}$ value and dispersant concentration necessary to attain high zeta potential. The control of deposition voltage and time is also important for good quality thin films deposits. The Further, this study shows that EPD technique can be applied in the design of inexpensive waste water purification systems for light industries before discharge into the ecosystem.

\section{Conclusions}

This paper presents the results of experimental study of photocatalytic activity of $\mathrm{TiO}_{2}$ nanoparticles thin films prepared by the EPD method. Salient conclusions arising from the study are summarized below.

1. Ethanol was found to be a better solvent compared to propanol, water or toluene. A pH of 3 gave the best suspension stability with a $\mathrm{TiO}_{2}$ solid loading of $4.0 \mathrm{wt} \%$ and iodine dispersant concentration of $0.2 \mathrm{wt} \%$ with respect to $\mathrm{TiO}_{2}$ concentration. An applied voltage of 20.0 $\mathrm{V}$ was optimum for electrophoretic deposition of $\mathrm{TiO}_{2}$ on glass substrate, while time was varied accordingly depending on the required thickness. These optimum parameters gave a good quality film in terms of adherence to the substrate, homogeneity of the film and minimal micro cracking upon drying.

2. The photocatalytic activity of $\mathrm{TiO}_{2}$ thin films decreased nearly exponentially with illumination time of the ultraviolet light (UV) and was further dependent on film thickness, sintering temperature and the intensity of the UV light. Highest rate of photocatalytic activity was observed at an optimal film thickness of $95.0 \pm 2.0 \mu \mathrm{m}$ sintered at $300.0^{\circ} \mathrm{C}$.

3. Sintering at elevated temperatures beyond $700.0^{\circ} \mathrm{C}$ resulted in less photocatalytic activity due to change of phase from anatese to the less photoactive rutile phase of $\mathrm{TiO}_{2}$. At higher UV intensity, the photocatalytic activity was higher while decomposition of phenol was faster at elevated solution temperatures due to increased solubility of oxygen which acted as electron scavenger and prevented the recombination of electron-hole pairs.

\section{References}

[1] Kowalska S. and Bukowska B. (2003). The presence and Toxicity of Phenol Derivatives -Their effect on Human Erythrocytes. Current Topics in Biophysics, 27 (1-2), 43-51.

[2] Kazuya N. and Akira F. (2012). $\mathrm{TiO}_{2}$ photocatalysis: Design and applications Journal of Photochemistry and Photobiology C: Photochemistry Reviews, 13. 169- 189.

[3] Mathews R. W. (1992). Photocatalytic oxidation of organic contaminants in Water: An Aid to Environmental Preservation. Pure \& Applied Chemistry, 64 (9), 1285-1290.

[4] Ray K. and Preety S. (1999). Major Challenges in the Design of a Large-Scale Photocatalytic Reactor for Water Treatment. Chemical Engineering Technology, 22, 253-260.

[5] Blake D., Pin-Ching M., Zheng H., Edward J., Huang W. (1999). Application of the Photocatalytic Chemistry of $\mathrm{TiO}_{2}$ to Disinfection and the Killing of Cancer Cells. Separation and Purification Method, 284, 1-50.

[6] Porter J., Li G., Chan K. (1999). The Effect of Calcinations on the Microstructural Characteristics and Photoreactivity of Degussa P$25 \mathrm{TiO}_{2}$. Journal of Material Science, 34, 1523-1531.

[7] Boccacini A. and Zhitomisrky I. (2002). Application of Electrophoretic and Electrolytic Deposition Techniques in Ceramic Processing. Current Opinion in Solid State and Material Science, 6, 257-260.

[8] Van der Biest O. and Vandeperre L. (1999). Electrophoretic deposition of materials. Annual Reviews Material Science, 29 (1), 327-352.

[9] Kawakita M., Uchikoshi T., Kawakita J. and Sakka Y. (2009). Preparation of crystalline-oriented Titania photoelectrodes on I-TO glasses from a 2-propanol-2, 4-pentanedione solvent by electrophoretic deposition in a strong magnetic field. Journal of the American Ceramic Society, 92 (5), 984-989.

[10] Laxmidhar B. and Meilin L. (2007). A review on fundamentals and applications of electrophoretic deposition (EPD). Progress in Materials Science, 52, 1-61.

[11] Sarkar P. and Nicholson P. (1996). Electrophoretic Deposition. Mechanism, Kinetics and Applications to Ceramics. Journal American Ceramics Society, 79 (8). 1987-2002.

[12] Narayan M. R. and Raturi A. (2012). Deposition and characterization of titanium dioxide films formed by electrophoretic deposition. International Journal of Materials Engineering Innovation, 3 (1), 17-31. 
[13] Cabanas-Polo S. and Boccaccini A. (2015). Electrophoretic deposition of nanoscale $\mathrm{TiO}_{2}$ : technology and applications. Journal of the European Ceramic Society, http://dx.doi.org/10.1016/j.jeurceramsoc.2015.05.030.

[14] Moreno R. and Ferarri B. (2002). Advanced Ceramic via EPD of Aqueous Slurries. American Ceramic Society Bulletin, 79, 44-48.

[15] Radice S., Bradbury C., Michler J., Michler S., (2010). Critical particle concentration in electrophoretic deposition. Journal of the European Ceramic Society. 30(5). 1079-1088.

[16] Van Tassel J. and Randall C. (2006). Mechanisms of electrophoretic deposition. Key Engineering Materials, 314, 167-174.

[17] Besra L. and Liu M. (2007). A review of fundamentals and applications of electrophoretic deposition (EPD). Progress in Materials Science, 52 (1), 1-61.

[18] Jun-Ho Y., Seok-Soon K., Dong-Yu K. and Yung-Eun S. (2005). Electrophoretically deposited $\mathrm{TiO}_{2}$ photo-electrodes for use in flexible dye-sensitized solar cells. Journal of photochemistry and Photobiology A: Chemistry 173. 1-6.

[19] Miyasaka T. and Kijitori Y. (2004). Low-temperature fabrication of dye-sensitized plastic electrodes by electrophoretic preparation of mesoporous $\mathrm{TiO}_{2}$ layers. Journal of the Electrochemical Society, 151 (11). 1767-73.

[20] Bandy J., Zhang Q. and Cao G. (2011). Electrophoretic deposition of titanium oxide nanoparticle films for dyesensitized solar cell applications. Materials Sciences and Applications, 2 (10), 1427-1431.

[21] Yum J-H., Kim S-S., Kim D-Y. and Sung. Y-E. (2005). Electrophoretically deposited $\mathrm{TiO}_{2}$ photo-electrodes for use in flexible dye-sensitized solar cell. Journal Photochemistry and Photobiology A: Chemistry, 173 (1), 1-6.

[22] Xue Z., Zhang W., Yin X., Cheng Y., Wang L. and Liu B. (2012). Enhanced conversion efficiency of flexible dyesensitized solar cells by optimization of the nanoparticle size with an electrophoretic deposition technique. RSC $A d v$., 2, 7074-7080.

[23] Chiang W. T., Lee P. T. and Hsu R. Q. (2015). Study on Preparation of Flexible Semiconductor Electrode for Dyesensitized Solar Cells by EPD. Manufacturing Science and Technology, 3 (4): 170-176.

[24] Jarernboon W., Pimanpang S., Manesiri S., Swatsitang E. and Amornkitbamrung V. (2009). Optimization of titanium dioxide film prepared by electrophoretic deposition for dyesensitized solar cell application, Thin Solid Films, 517 (16), 4663-4667.
[25] Miyasaka T. and Kijitori Y. (2004). Low-temperature fabrication of dye-sensitized plastic electrodes by electrophoretic preparation of mesoporous $\mathrm{TiO}_{2}$ layers. Journal of Electrochemical Society, 151 (11), A1767-A1773.

[26] Chiu W-H., Lee K-M. and Hsieh W-F. (2011). High efficiency flexible dye-sensitized solar cells by multiple electrophoretic depositions. Journal of Power Sources, 196, 3683-3687.

[27] Benehkohal N. (2013). Innovations in Electrophoretic Deposition of Nanotitania-based Photoanodes for Use in Dyesensitized Solar Cells. PhD Thesis, McGill University.

[28] Damodaran R. and Moudgil B. M. (1993). Electrophoretic deposition of calcium phosphates from non-aqueous media. Colloids and Surfaces A: Physicochemical and Engineering Aspects, 80. 191-195.

[29] Sarkar, P., Datta, S. and Nicholson, P. S. (1997). Functionally graded ceramic/ceramic and metal/ceramic composites by electrophoretic deposition. Composites Part B: Engineering, 28 (1), 49-56.

[30] Ma J. and Cheng W. (2002). Electrophoretic Deposition of Lead Zirconate Titanate Ceramics. Journal American Ceramics Society, 85 (7), 1737-1740.

[31] Put S., Biest O., Anne G., Vleugels J. (2004). Microstructural Engineering of FGMs by Elecrophoretic deposition. Journal of Material Processing Technology, 143-144, 572-577.

[32] Allan M. (1976). The crystallization of anatese and rutile from amorphous titanium dioxide under hydrothermal conditions, American mineralogist, 61, 419-424.

[33] Inga N., Laura S., Liga S., Reriks J. and Jurijs O. (2017). Electrophoretic deposition of nanocrystalline $\mathrm{TiO}_{2}$ particles on porous $\mathrm{TiO}_{2-\mathrm{x}}$ ceramic scaffolds for biomedical applications. Journal of the European Ceramic Society, 37, 3185-93.

[34] Wang M. and Peng K. (2003). Electrophoretic Deposition of Porous Hydroxyapatite Scaffold, Biomaterials, 24, 3505-3510

[35] Boccaccini A., Klein S., Ma R., Li Y. and Zhitomirsky I. (2010). Electrophoretic deposition of biomaterials. Journal of the Royal Society Interface, 7 (5), S581-S613.

[36] Murray M. S. (1941). Bromination of Phenols by Means of Bromide-Bromate Solution., Ind. Eng. Chem. Anal. Ed., 1941, 13 (1), 35-38.

[37] Chen D. and Ray K. J. (1999). Photocatalytic Kinetics of Phenols and its Derivatives Over UV Irradiated $\mathrm{TiO}_{2}$. Applied Catalyst B: Environmental, 23, 143-157.

[38] Chan A., Porter J., Barford P., Chan K. (2001). Photocatalytic Thin Film Cascade Reactor for Treatment of Organic Compounds in Waste water. Water Science and Technology, 44 (5), 187-195. 